\title{
Human Capital Management System Framework A Case Study in Malaysia
}

\section{Nor Hapiza Mohd Ariffin, Zan Azma Nasruddin}

To Link this Article: http://dx.doi.org/10.6007/IJARBSS/v11-i10/11058

DOI:10.6007/IJARBSS/v11-i10/11058

Received: 09 August 2021, Revised: 28 August 2021, Accepted: 19 September 2021

Published Online: 11 October 2021

In-Text Citation: (Ariffin \& Nasruddin, 2021)

To Cite this Article: Ariffin, N. H. M., \& Nasruddin, Z. A. (2021). Human Capital Management System Framework A Case Study in Malaysia. International Journal of Academic Research in Business and Social Sciences, 11(10), 349-359.

\section{Copyright: @ 2021 The Author(s)}

Published by Human Resource Management Academic Research Society (www.hrmars.com)

This article is published under the Creative Commons Attribution (CC BY 4.0) license. Anyone may reproduce, distribute, translate and create derivative works of this article (for both commercial and non-commercial purposes), subject to full attribution to the original publication and authors. The full terms of this license may be seen at: http://creativecommons.org/licences/by/4.0/legalcode

Vol. 11, No. 10, 2021, Pg. 349 - 359

Full Terms \& Conditions of access and use can be found at http://hrmars.com/index.php/pages/detail/publication-ethics 


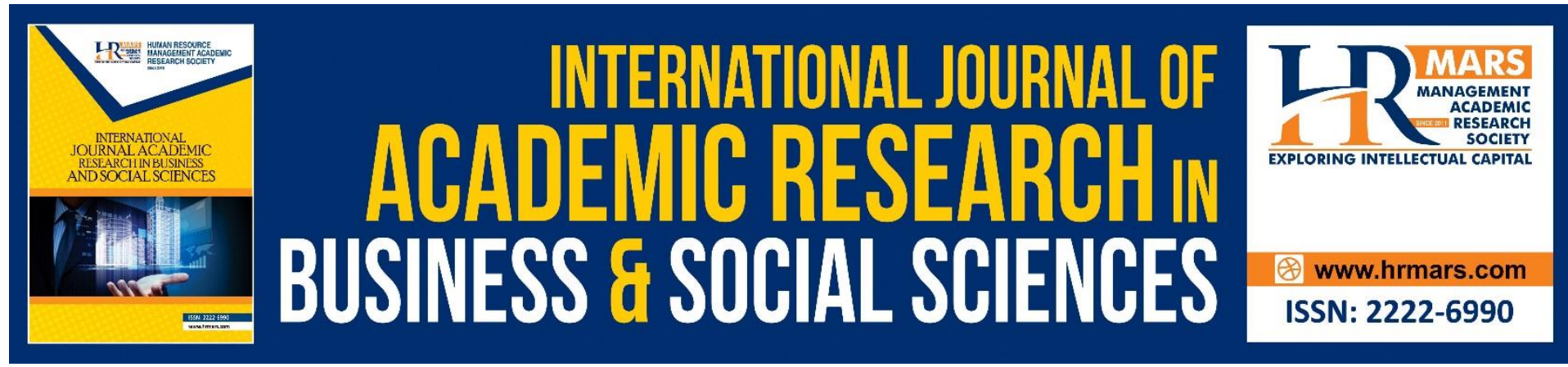

\title{
Human Capital Management System Framework A Case Study in Malaysia
}

\author{
Nor Hapiza Mohd Ariffin, Zan Azma Nasruddin \\ Faculty of Computer and Mathematical Sciences, Universiti Teknologi Mara, Shah Alam, \\ Selangor, Malaysia
}

\begin{abstract}
This study was initiated by discussions on organizational management theory and led readers to explore issues in organizational management that focused on humanity. There is criticism from previous researchers on the weakness and neglect of this concept of humanity in the theory of conventional information system management. The literature review of the prior study also found neglect of focus on the human being and the weaknesses that need to be improved in developing the Human Capital Management system framework. This study aims to develop a framework that empowers a key focus of humanity management. In developing the Human Capital Management system, decisions are taken to apply conventional information management theory with humanity management theory by focusing on human capital improvements. A case study on the organization through interviews using a purposive sampling approach has been conducted. As a result of the case studies, a Human Capital Management system framework which is named HCM-i, was developed. Thus, in the future time, it is hoped that this framework can be adapted in any information systems development as part of the social-technical approach.
\end{abstract}

Keywords: Human Capital, Organizational Management, Humanity Management, Management System

\section{Introduction}

Companies around the world are working to incorporate social responsibility into their business model. They recognize that their profits are rising and gaining long-term sustainability if they develop "humanity" in their business model (Camilus et al., 2017). Hence, humanity can be an economic driver, environment, and social sustainability. This exciting development is a widely seen global phenomenon. The Humanities approach began from the 1990s to the present. According to Abd Aziz (2007), the humanity approach comes from weaknesses in conventional management approaches such as the Open System Approach (1960-1970s) and the Contingency Approach (1970-1980s). He further explained that these two approaches are no longer capable of addressing the various problems arising from the denial of the interests of humanity within the organization.

The literature review finds that organizational management thinks that the only way to overcome the problem is to focus on the element of humanity. This fact was acknowledged by Wiese and Buckley (1998) as a result of their study of the management's performance on 
conventional performance evaluation. Therefore, according to them, a new approach should be introduced to replace the conventional approach. Furthermore, it brings researchers to investigate and compare the concepts of Western management and Islamic management.

\section{Literature Review}

From a literature review, it is found that Insan is a pronoun in Arabic which, if referred to the English language, is called human. However, Insan's word translation as human in English does not reach the real meaning of the term because Western researchers do not understand the term Insan through the perspective of revelation in Islam. However, some Western researchers refer to the term Insan with human spirit (Bartlett \& Ghoshal, 1995). This opinion is also parallel to Western researchers such as Covey (2004), suggesting that the mind, spirit, and body need to be balanced and develop simultaneously in all its time. It is also supported by Holman et al (2002), which states, "Human beings being made up of body, mind, emotions and spirit, to be in harmony with the unseen order of things, firstly require us to believe in this unseen order ". He suggested spirituality as a part of management. Wells et al (2007) also gave an opinion on the need to harmonize technology, processes, and humans to manage change management efficiently. He said, "This human dimension should not be underestimated". Bartlett and Ghoshal (1995) also agree on the needs of the human element and the approach of humanity as an important element in management by suggesting, "The new role of top management is to unleash the human spirit which makes initiative, creativity and entrepreneurship". This opinion is interesting as they realize that an internal factor motivates a person to have high-quality human capital. It naturally occurs when that personhood reaches the perfect level within one's self.

Islamic scholar Imam Al Ghazali in his famous book, Ihya Ulumuddin, explained these four elements by explaining the role of each element in human beings. According to him, humans consist of four main elements: physical, mind, lust, and spirit. With these four elements, then humans can function as humans in the real sense. Table 1 describes the summary of the role of each element in the concept of humanity obtained through a literature review of the researcher on the idea of the human in Islamic perspective from the book of Ihya Ulumuddin.

\section{Table 1: The role of the four elements on human}

\begin{tabular}{ll}
\multicolumn{1}{c}{ ELEMENTS } & \multicolumn{1}{c}{ ROLES } \\
$\begin{array}{l}\text { Physical } \\
\text { Mind }\end{array}$ & $\begin{array}{l}\text { Act. Do it. Implement as directed. } \\
\text { Receive knowledge and information. Whether the information is correct or } \\
\text { not, useful or not, the information is only collected. }\end{array}$ \\
Lust & $\begin{array}{l}\text { Stimulate and expect either good or bad will, halal or haram, positive or } \\
\text { negative } \\
\text { Spirit }\end{array}$ \\
& $\begin{array}{l}\text { The role of the spirit is to feel. The senses are like waves coming from various } \\
\text { elements of physical, mind or lust. }\end{array}$ \\
\hline
\end{tabular}

Furthermore, Imam Al Ghazali summed up this role by stating that the spirit is the leader, the mind is the thinker, the lust is the catalyst, and the Physical is the executor. Therefore, the findings were concluded by producing Figure 1. 


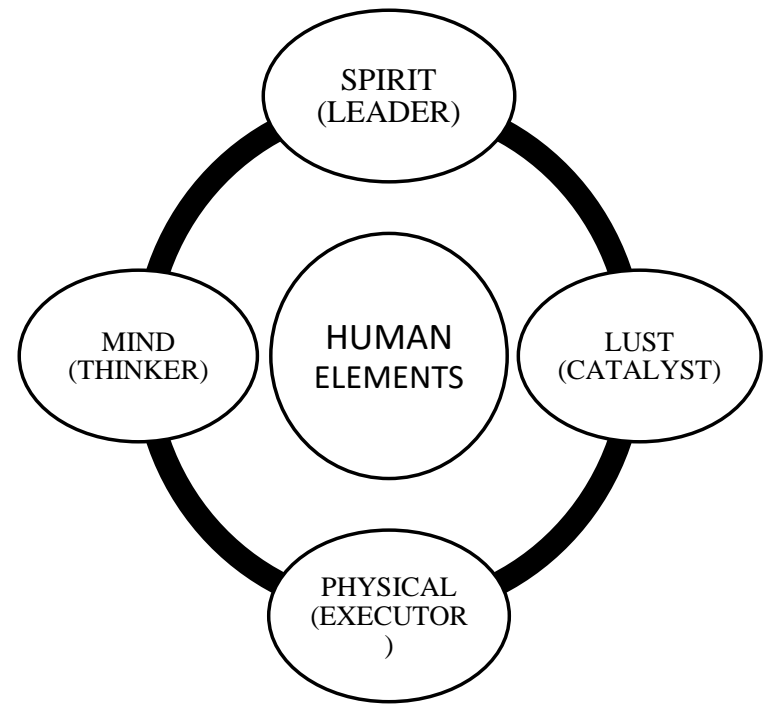

Figure 1: Relationship between elements in humans

Figure 1 shows the relationship between elements that generate continuity between the human elements that consists of spirit, lust and mind with the external factors of the human being, i.e. the physical body. However, it also found a significant difference between the concepts of Western management and the concept of Islamic management as both the management in terms of philosophy and concept was very different.

In general, the concept of Western management receives materialistic and secular living views. In contrast, the idea of Islamic management embraces the paradigm of the tauhid paradigm and the balance between the world and the hereafter. The concept of humanity in management that places the human element as the most important element in strategic management requires blending with Islamic management. If viewed from an Islamic perspective, organizational management must start from and end with the question of the principal, which is about the nature of human events (Abd Halim, 1996).

In contrast, based on Western strategic management systems, humanitarian studies are only studied at the social dimension level covering culture, interaction with stakeholders, and knowledge domain. At the same time, the human element itself is a neglected entity. As a result, it led to Western researchers who did not relate much to value systems, community cultures and religious beliefs.

The value system and the view of life are fundamental to building the identity and intellect of society. It affects the success of the management of the people themselves. Negligence of this dimension will cause difficulties in the management of change in the organization. In contrast, the willingness to change in the management business process and the willingness to change within the organization is the success factor of an organization.

According to Wan Liz (1996), what needs to be done in the concept of humanity under Islamic management, is organizational renewal through the transformation of work culture and management practices. He suggests that efforts are made to change the corporate culture by adopting an approach based on sound local foundations. Figure 2 shows the linkages between strategic management processes and fundamental Islamic goals in the context of organizational change. 


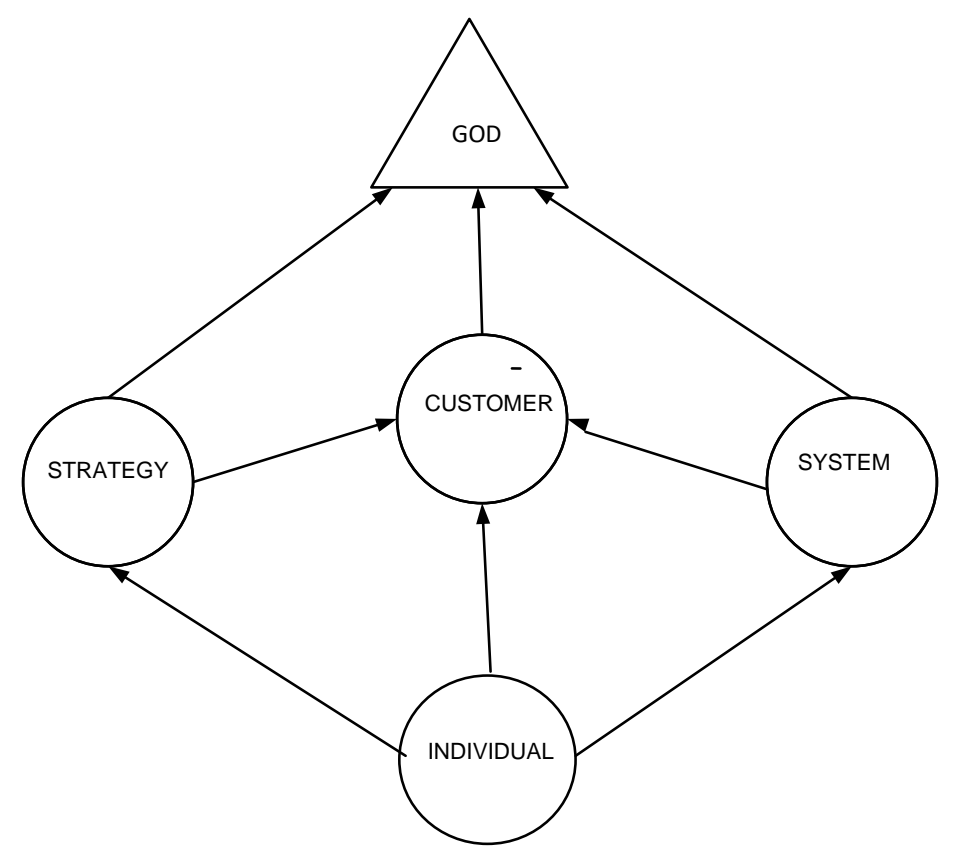

Figure 2: Islamic Management Concept (Wan Liz, 1996)

In this regard, he referred to the organization as a system or structure, strategy as measures to achieve the concept of Islamic management organizations, individuals representing the organization's members who will implement the changes and customers as the public who receive services organization. Therefore, wan Liz (1996) argues that the human element is important in managing change in the strategic management of an organization.

As discussed previously, the human context of Islam consists of four elements, namely mind, lust, spirit and physical body. So when it comes to human capital, then measurements on it must be based on the four elements. In the theory of intelligence, four bits of intelligence are possessed by human intelligence, whose intelligence uses IQ (Intelligent Quotient), emotional intelligence whose measurement uses EQ (Emotional Quotient) and spiritual intelligence measurements using SQ (Spiritual Quotient) while the body or physical measured in physical fitness (Physical Intelligence). Professor Stephen R. Covey supports this opinion in his article "A beautiful insight about $P Q, I Q$, EQ and SQ", which proposes the formula below:

$$
\text { Holistic Development - [Integration: SQ + EQ + IQ + PQ = Wisdom }]
$$

According to him, the development of holistic human capital must integrate into these four bits of intelligence to gain the wisdom of the people themselves. Therefore, it forms an asset or becomes capital to a human being, and when it is integrated, the human being can be called human. It is the real form of human capital. This opinion is a view that has long been discussed by Islamic scholars such as Imam Ghazali hundreds of years ago. However, it is like a discovery to Western researchers, but this understanding has been characterized since the time of the Prophet Muhammad SAW again in terms of Islamic knowledge. In summary, holistic human beings can be described as in Figure 3. 


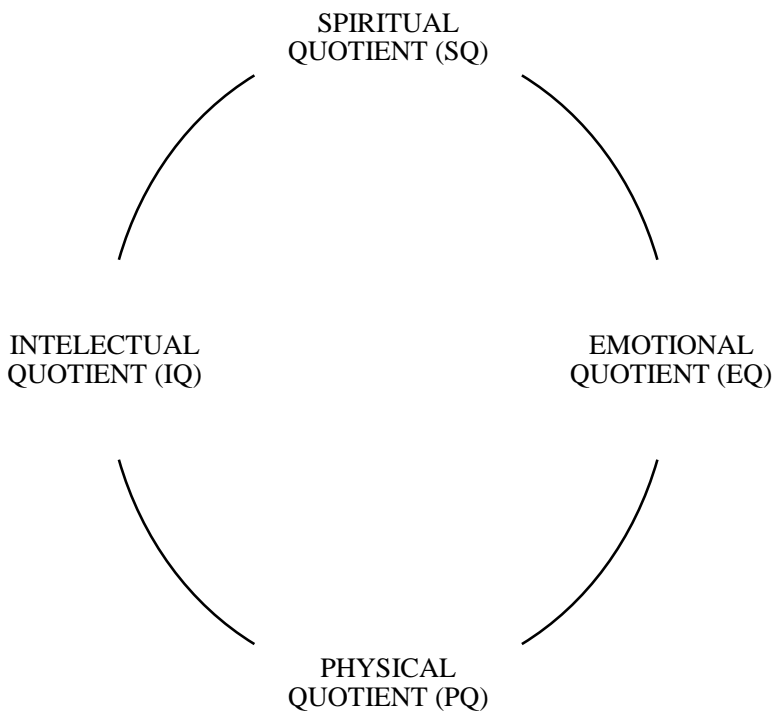

Figure 3: Holistic Human Capital model

The literature review has led researchers to explore the concept of management in Islam and found that humanitarian management refers to human capital development holistically in organizational management. Marglani (2006) proposes the Moral ISO based on three-dimensional trees, namely knowledge, charity and ethics. It gives the researcher an overview that the development of the soul (mind, spirit and lust) will be born spiritual civilization. The development of this humanity will lead to the excellence of organizational management and the development of a safe physical civilization. In short, humanity management requires a combination of physical, mental, and spiritual, which hinges on the moral as humanity's holistic measurement. Thus, assessing the concept of religion inspires researchers to propose a human capital management system that will be discussed later.

\section{Human Capital Management System}

In developing the Human Capital Management system, decisions are taken to apply conventional management theory with humanity management theory by focusing on human capital improvements. According to Kotler (1980), when we need individuals who can give leadership to the organization, we also need people to develop a culture that will shape that leadership. This statement shows that the change in organizational attitudes is from individuals, and this gives strong support to this research idea that puts human dimensions components within the framework of the Human Capital Management system. The most important thing is the individual's self-preparation in putting himself as an entity involved in the organization life cycle. Therefore, change management is needed in an organization to address changes that lead to the need to increase human capital to support the process of change.

Humans balance physical and spiritual demands, so organizations need to meet some of their customers' needs, especially internal organizational customers. According to Abd Aziz (2007), both demands must be completed by the organization. Some examples of physical demands that organizations need to meet are:

i. Provision of development training programs,

ii. Effective performance evaluation, 
iii. Salary and rewards,

iv. Performance development career,

v. Good employee relations,

vi. Safety and health of workers

Whereas the spiritual demands are to ensure that every member of the organization is trustworthy, honest and integral, have emotional stability, have a cheerful working environment, and get justice regardless of race, religion, skin colour, etc. The concept focuses primarily on customers or people themselves. Humanity improvements can be made by providing training, service incentives, rewards, and ongoing monitoring of the organization by providing motivation, continuous learning opportunities through courses, leadership empathy and customer satisfaction, humanitarian concerns, precise unity within the organization and impetus to ensure the goal being a perfect human being achieved. With that, there will be a balance between the four elements in the human being - between the mind, the lust, the spiritual and the physical. It also adds value to individual human capital in particular and raises the organization's value in general.

In conclusion, the organization needs to pay attention to the development of the people to realize the organization's vision and mission. Therefore, the practice of this spiritual concept is important in the individual and the organization's environment in the workplace. Furthermore, with good spiritual practice, the organization can increase productivity and customer relationships through excellent work ethics. Based on previous researches, the researcher proposes several phases and appropriate benchmarks items as in Table 2 to develop the Human Capital Management system (Wan Liz (1996); Abd Halim (1996); Jain (2003); Abd Aziz (2007); Nick \& Alexander (2007); Anthony et al. (2015), Ann \& James (2018)).

TABLE 2: Phases and Benchmarks Items in Human Capital Management System Framework

\begin{tabular}{|c|c|c|c|}
\hline HUMANITY & HUMANITY & HUMANITY & HUMANITY \\
\hline PREPARATION & DEVELOPMENT & MANAGEMENT & IMPROVEMENT \\
\hline Intellectual & Patience & Shura & Strength of Faith and \\
\hline accuracy & Trust & Cooperation & Believe \\
\hline Leadership Stability & Sincere & Be ethical & Deep knowledge \\
\hline Expertise & Honest & Morality & The precision of \\
\hline Lifelong Learning & Efficient & Integrated & practice and action \\
\hline Emotional Strength & Creative & Whole & Excellence in morals \\
\hline Goodness of morals & Fair & Deriving reason and & \\
\hline Integrated & Clean & revelation & \\
\hline Education & gratitude & Uphold truth & \\
\hline Transparency & Not giving up & Prevent evil & \\
\hline soul & morality & Consensus & \\
\hline Mastery & Dedication & Muhasabah & \\
\hline technology & Disciplined & Transparency & \\
\hline Spirituality & Responsible & Spiritual motivation & \\
\hline Attitude Transformat & $\begin{array}{l}\text { Diligent } \\
\text { Simple }\end{array}$ & Scientific & \\
\hline
\end{tabular}


Next, Table 3 is proposed to be used as an organizational guide to ensure that every work activity is practised following the spirituality and moral values within the Human Capital Management system.

\section{Table 3: Moral Values Policy}

Items

1. Recognize the real self by assessing the extent to which spiritual values exist within oneself.

2. Changing your personality is based on the spiritual characteristics that can shape your personal qualities

3. Apply pure and ethical values in making decisions concerning personal and organization

4. Ensure self-purity in physical and spiritual health

5. Have a good sense of attitude and respect for others

6. Improve productivity and creativity in oneself

7. Exploit the ability of the person in terms of physical, mental, emotional and self-motivation

8. Adopting teamwork and improving individual relationships

\section{Case Study in Organization}

A case study was conducted in Malaysia's Research and Development Centre (R \& D) of Public Higher Learning Institutions. Organisation X's R \& D centre is created to manage research, consulting, and research publications. In line with the aspirations of organization $X$ to become a research university, the $R \& D$ centre of organization $X$ catalyzes new research and innovation activities. There are 42 staff at the $R \& D$ Centre in this organization $X$. There are six divisions in the $R$ \& $D$ Centre of organization $X$, including Consultancy, Publication, Innovation, Administration, ICT Research and Support. These sections are responsible for managing, monitoring and implementing science and technology research, social science research and management, consulting, finance for INFOREC (Information for Research and Consultancy) consultancy, innovation, publication and database.

Data collection for this case study were obtained from various levels of staff from top management to support management at $R$ \& $D$ Centre of the organization $X$ whose identified as suitable to be respondents to this case study. Sampling is done by purposive sampling. A total of 15 staff members of the $R \& D$ Centre of organization $X$ were involved as respondents by providing feedback for interviews conducted to implement the pioneering development of the Human Capital Management system. In addition, respondents were interviewed to evaluate and provide feedback based on the recommendations made by the researcher from Table 2 and Table 3.

In summary, for this case study, researchers have suggested phases and assessment methods to implement the Human Capital Management system framework. This recommendation is based on interviews with staff from the $R \& D$ Centre of organization $X$ and give the name of this framework as HCM-i. Figure 4 outlines the recommendations. 

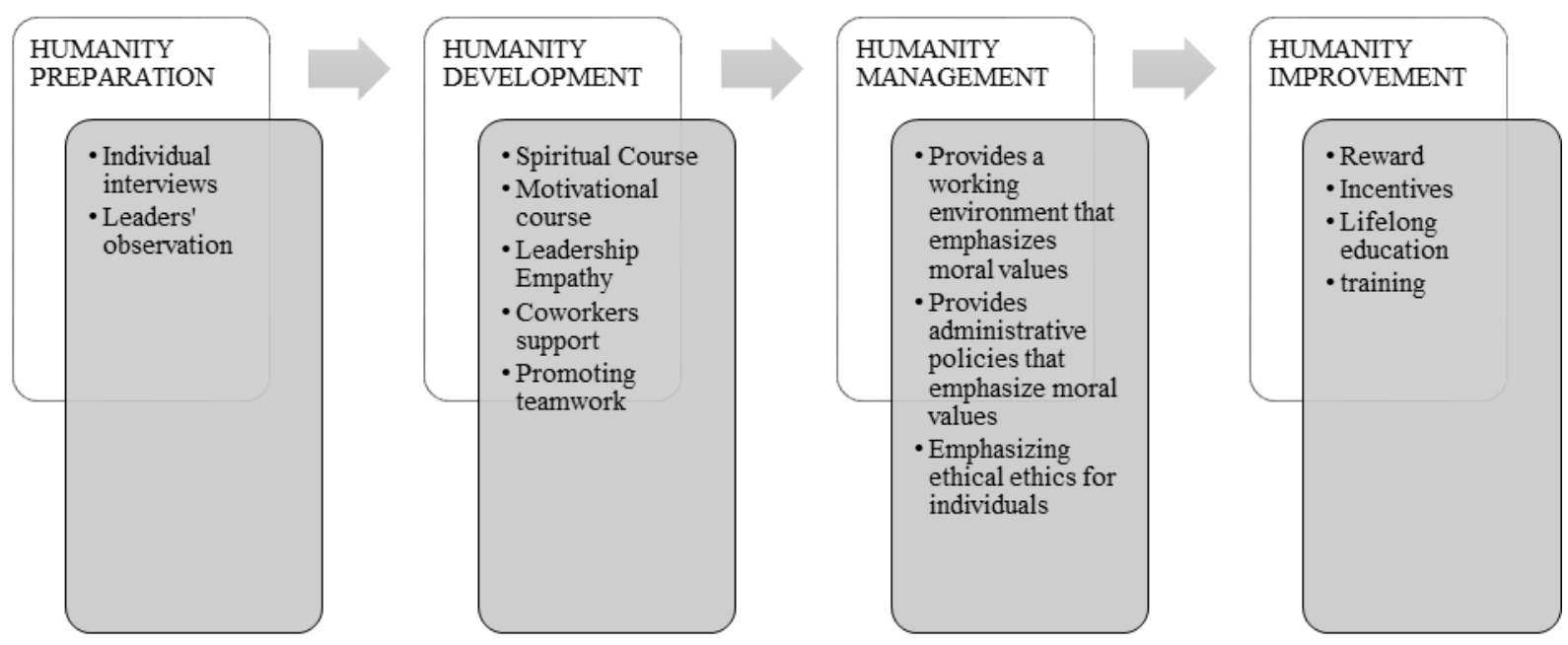

Figure 4: Human Capital Management System Framework (HCM-i)

This Human Capital Management System framework (HCM-i) is unique because it is according to its environment. The effectiveness of the implementation depends on the extent to which the management has the awareness and understanding of the importance of human capital development within their organization. The tools or techniques that can be used to support the evaluation of the Human Capital Management system are questionnaires, interviews, head office assessments, colleagues' assessments and so on. The organization's top management plays an important role in this Human Capital Management system. However, the overall management system directly depends on the organizational leader's style and self-interest in developing human capital organization under their responsibility.

\section{Discussion}

The absence of the humanity improvement process in the previous study is not surprising. Past studies are based on secular paradigm-oriented conventional management theory that does not see humans as components with spiritual or spiritual aspects. According to humanity management theory, as discussed in this paper, the spiritual aspect is the most important aspect that drives the well-being of the world and the end of the human being. This aspect has been neglected by past studies that conform to the total conventional management theory.

In addition, there is criticism from past researchers about weaknesses and neglect of this concept of humanity in conventional information systems management theory (Mehmet \& Burcin, 2016). This idea can be seen from the proposals and suggestions proposed by Jain (2003). According to him, the purpose of implementing conventional management systems is not based on social benefits. Through his research on the history of the information system model, he found that from 2000 onwards, the development of the organizational management system model requires a perspective shift by looking at humans as the main focus.

This opinion was also supported by a literature review from the previous study, which found that there was still negligence on the human element. These weaknesses need to be improved in developing the Human Capital Management system framework. Hence, the researcher developed the proposed framework, namely $\mathrm{HCM}-\mathrm{i}$, by placing the human being as the main focus of the management of the organization and thus be a framework that puts human beings as the main focus of the organization's management as suggested by Holman (2002), Jain (2003), Wells (2007) and Maurizio and Filippo (2018). 
The Islamic management theory was centuries ago through its main sources of the Quran and Hadith. The opinions of Islamic scholars suggest that in any system, humanity is a key aspect that ensures the success of such a practice. The scope brought about by Islam is far beyond the current situation and even across the world's natural boundaries. Hence, this HCM-i is suitable for non-profit organizations such as the public sector and the education sector. It is also ideal for for-profit organizations with little modification in terms of vision, mission and objective.

Today, human resource management has shifted from merely earning profit from customers and employees solely towards the awareness that Human Capital has a value in achieving organizational competitive advantage. The issue of Human Capital has now become increasingly popular (Mellander \& Florida, 2021). Human Capital has been regarded as a strategic responsibility to be known and mastered by managers or organizational leadership if they want to bring new changes and values within their respective organizations.

Human Capital is defined as a set of knowledge, skills, experience and attitudes that individuals possess in an organization and can be regarded as a critical resource for the future challenges and competition of the organization (Samad, 2020). Human Capital is a superiority of personality possessed by humanity through the mastery of knowledge, high skill and praiseworthy character. From an Islamic perspective, Human Capital looks at the rate of return on investment to the organization and the rate of return on the perfection of the practices undertaken to be recognized as the best practice to be rewarded not only in the world but also leads to the hereafter.

\section{Conclusion}

For a future study, there are many more issues to be examined, such as performance measurement and evaluation on the framework of the Human Capital Management system and how the Islamic approach can be adopted or adapted to improvise the framework, especially concerning the elements of humanity.

This study has led a vision towards human capital, focusing on proposing the framework of the Human Capital Management system. It is hoped that HCM-i can guide the organization regardless of the public or private sector to be the basis of the strategic management approach for customer relationship management in realizing the management of customer-oriented organizations. Furthermore, at the same time acknowledging the development of human capital within their organization.

\section{References}

Yusof, A. (2007). Keinsanan dalam Pengurusan. Cheras, Kuala Lumpur : Utusan Publications \& Distributors Sdn Bhd.

El Muhammady, A. H. (1996). Pengurusan Dalam Islam. Kuala Lumpur : Blue-T Communication Sdn Bhd.

Ann, M., \& James, G. (2018). Human capital loss in an academic performance measurement system. Journal of Intellectual Capital 19 (1): 53-70

Anthony, T. M., Herbert, G. H., \& Steven, M. K. (2015). Review Of Teaching Performance Assessments For Use In Human Capital Management. Available at https://files.eric.ed.gov/fulltext/ED506953.pdf

Al-Ghazali, I. (1982) Ihya' Ulumuddin. Singapura : Pustaka Nasional.

Bartlett, C., \& Ghoshal, S. (1995). Rebuilding Behavioural Context: Turn Process Reengineering into People. Rejuvenation.Sloan Management Review. pp 11-23 
Camillus, J., Bidanda, B., \& Mohan, N. C. (2017) The Business of Humanity: Strategic Management in the Era of Globalization, Innovation, and Shared Value. New York: Taylor and Francis

Covey, S. R. (2004) The Eight Habits From Effectiveness to Greatness. London: Simon \& Schuster UK Ltd.

Holman, D., Wall, T. D., Clegg, C. W., Sparrow, P., \& Howard, A. (2002) The new workplace: A guide to the human impact of modern working practices. West Sussex, UK: Wiley.

Marglani, M. (2006) ISO Akhlak: Praktik Tasauf Islam Antarabangsa. Kuala Lumpur : Penerbitan Minda Ikhwan.

Maurizio, B., \& Filippo, E. C. (2018) Human factor risk management in the process industry: A case study. Reliability Engineering and System Safety 169: 149-159

Mehmet, U., \& Burcin, H. (2016) Human Aspect as a Critical Factor for Organization. Sustainability in the Tourism Industry. Available at http://www.mdpi.com/20711050/8/3/232/pdf

Mellander, C., Florida, R. (2021) The Rise of Skills: Human Capital, the Creative Class, and Regional Development. In: Fischer M.M., Nijkamp P. (eds) Handbook of Regional Science. Springer, Berlin, Heidelberg. https://doi.org/10.1007/978-3-662-60723718

Nick, B., \& Alexander, S. (2007) The moderating role of human capital management practices on employee capabilities. Journal of Knowledge Management. 11 (3): 31-51

Samad, S. (2020). Achieving innovative firm performance through human capital and the effect of social capital. Management \& Marketing. Challenges for the Knowledge Society, 15(2), 326-344. https://doi.org/10.2478/mmcks-2020-0019

Wan Omar, W. L. O. (1996) Pengurusan Islam Abad ke 21 : Revolusi Pengurusan untuk keunggulan sektor awam dan korporat. Kuala Lumpur : Utusan Publication \& Distributors Sdn Bhd.

Wells S., Burgess, N., \& Ngusaru, A. (2007) Towards the 2012 (human dimension) marine protected area targets in Eastern Africa. Ocean and Coastal Management. 50: 67-83.

Wiese, D., Buckley, M. R. (1998) The evolution of the performance appraisal system. Journal of Management History. 4 (3): 233-249. 